\section{Introduction to Challenge Test and Microbiological Characterisation of Local Products}

\section{Andrea Serraino, Federica Giacometti}

Dipartimento di Scienze Mediche

Veterinarie, Alma Mater Studiorum Università di Bologna, Ozzano dell'Emilia (BO), Italy

With the entry in force of Regulation (EC) No 178/2002 of the European Parliament and of the Council of 28 January 2002 (European Commission, 2002) laying down the general principles and requirements of food law, establishing the European Food Safety Authority and laying down procedures in matters of food safety, a more clear specification of the responsibilities of food business operator (FBO) was introduced in the EC legislation: food and feed business operators at all stages of production, processing and distribution within the businesses under their control shall ensure that foods or feeds satisfy the requirements of food law which are relevant to their activities and shall verify that such requirements are met. In detail food shall not be placed on the market if it is unsafe (injurious to health or unfit for human consumption). According to Article 4 of Regulation (EC) No 852/2004 (European Commission, 2004), food business operators are to comply with microbiological criteria. which were set in Commission Regulation (EC) No1441/2007 of 5 December 2007 (European Commission, 2007) amending Regulation (EC) No 2073/2005 (European Commission, 2005) on microbiological criteria for foodstuffs. An interesting news of the Community legislation were food safety criteria for $L$. monocytogenes in ready-to-eat (RTE) food: FBO are therefore called to perform activities to evaluate the behaviour of $L$. monocytogenes in their products and to demonstrate to the Authorities, by microbiological challenge tests, the justification of their choices (AFSSA, 2008).

Microbiological challenge testing is a useful tool for determining the ability of a food to support the growth of spoilage organisms or pathogens. Microbiological challenge tests also play an important role in the validation of processes that are intended to deliver some degree of lethality against a target organism or group of target organisms. Quite often, with this latter purpose, there is an associated performance standard that the process must deliver (Health Canada, 2012).

Microbiological challenge studies are also useful in determining the potential shelf life of certain refrigerated or ambient-stored foods. The determination of whether challenge studies are appropriate or useful must be made by considering such factors as the likelihood of the product to support growth of spoilage organisms or pathogens, or a knowledge of the previous history of the product.

Moreover, the production system in Europe is characterised by two main types of productive activities: an industrial production system, characterised by high automation level and standardized productions, and an artisanal one characterized by artisanal manufacture. In this latter category, more frequently represented in the Mediterranean countries, a significant part of the food productions are designated to protected designation of origin productions or traditional products, which are frequently characterized by the use of raw materials and, in fermented products, of natural microbial starters cultures. Microbial food cultures are live bacteria, yeasts or moulds used in food production that carry out the fermentation process in foodstuffs; fermentation, used by humans since the Neolithic period (around 10,000 years $\mathrm{BC}$ ), helps to preserve perishable foods and to improve their nutritional and organoleptic qualities (taste, sight, smell, touch) (Prajapati and Nair, 2005). When fermented product is produced following traditional procedures from raw material, the environmental microbiota plays a fundamental role in fermentation and is one of the most important parameters that influence the product quality. In addition, the biodiversity of bacteria involved in cheese production can be considered a fundamental factor for the maintenance of the typical features of traditional cheese products (Marino et al., 2003).

On the other hand, the composition of natural cultures is complex and extremely variable and the use of such techniques is steadily decreasing in developed countries and some of these even prohibit the back-slopping technique because of the potential to magnify pathogen loads to very dangerous levels (Ross and Shadbolt, 2001). Moreover the effect on different foodborne pathogens in traditional products depends from the complexity of interaction of the indigenous microbiota activity and additional preservative action such as curing, salting, drying, seasoning, effect of added preservatives and so on.

Scientific studies characterize microbial food cultures traditionally used in food fermentation taxonomically, physiologically, biochemically and genetically, allowing a better understanding and an improvement of traditional food processing, and could spread to new fields of applications. However, due to the great number and variety of artisanal products, it could be difficult for small artisanal businesses to perform challenge test or microbiological characterization for each typical product, disclosure the results and publish or communicate the data available. For these reasons the Editorial Board of the Italian Journal of Food
Correspondence: Andrea Serraino, Dipartimento di Scienze Mediche Veterinarie, Alma Mater Studiorum - Università di Bologna, Ozzano dell'Emilia (B0), Italy.

Tel.+39.051.2097332 - Fax: +39.051.2097346

E-mail: andrea.serraino@unibo.it

Key words: Challenge test, Microbiology, Readyto-eat and local products.

Received for publication: 4 February 2014. Accepted for publication: 5 February 2014.

This work is licensed under a Creative Commons Attribution 3.0 License (by-nc 3.0).

(C) Copyright A. Serraino and F. Giacometti., 2014 Licensee PAGEPress, Italy

Italian Journal of Food Safety 2014; 3:2270 doi:10.4081/ijfs.2014.2270

Safety decided to open a new section of the Journal dedicated to short original papers on the microbiological challenge tests and on the microbiological characterization of RTE and typical products. The data published may be a useful tool to collect the greatest number of available data possible and consequently it may be useful for researchers, businness and control authorities in order to be compare or use all these data in their work and activities.

Manuscripts with a short introduction that describes the main microbiological, chemical and physical characteristics of the investigated food and the production process, an accurate description of the methods and of the results and a short and focused discussion are welcome.

\section{References}

AFSSA, 2008. Technical guidance document on shelf-life studies for Listeria monocytogenes in ready-to-eat foods. AFSSA 1:1-31.

European Commission, 2002. Regulation of the European Parliament and of the Council of 28 January 2002 laying down the general principles and requirements of food law, establishing the European Food Safety Authority and laying down procedures in matters of food safety, 178/2002/EC. In: Official Journal, L 31/1, 01/02/2002.

European Commission, 2004. Regulation of the European Parliament and of the Council of 29 April 2004 on the hygiene of the foodstaf, 854/2004/EC. In: Official Journal, L 139/1, 30/04/2004.

European Commission, 2005. Commission Regulation of 15 November 2005 on microbiological criteria for foodstuffs, 2073/2005/EC. In: Official Journal, L 388/1, 
22/12/2005.

European Commission, 2007. Commission regulation of 5 December 2007 amending Regulation EC 2073/2005 on microbiological criteria of the foodstuffs, 1441/2007/EC. In: Official Journal, L 322/12, 07/12/2007.

Health Canada, 2012. Listeria monocytogenes challenge testing of refrigerated ready-toeat foods. Bureau of microbial hazard, food directorate, health products and food branch. Available from: http://www.hcsc.gc.ca/fn-an/legislation/pol/ listeria_monocytogenes-test-eng.php

Marino M, Maifreni M, Rondinini G, 2003. Microbiological characterization of artisanal Montasio cheese: analysis of its indigenous lactic acid bacteria. FEMS Microbiol Lett 229:133-40.
Prajapati, JB, Nair BM, 2003. The history of fermented foods in Fermented Functional Foods. In: E.R. Farnworth (ed.), Handbook of fermented foods. CRC Press, Washington, DC, pp 1-25.

Ross T, Shadbolt C, 2001. Predicting Escherichia coli inactivation in uncooked comminuted fermented meat products. Meat and Livestock Australia ed., Sydney. 